\title{
Planning Regional Flood and Coastal Erosion Foresight Studies
} US Army Corps of Engineers ${ }_{\circledast}$

by Martin T. Schultz, Susan E. Durden, Paul B. Sayers, Ben P. Gouldby, Jonathan D. Simm, William R. Curtis, and Jack E. Davis

PURPOSE: This Coastal and Hydraulics Engineering Technical Note (CHETN) provides general information on planning regional Foresight studies to assess future flood and coastal erosion risks.

INTRODUCTION: Foresight studies are comprehensive scenario based investigations into major policy issues that encourage systematic thinking to illuminate the relationship between policy choices that are being made today and the range of potential outcomes associated with those choices that may be realized in the future. By revealing how the decisions of today may affect outcomes in the future, policy makers have the opportunity to internalize and account for future costs and benefits when making decisions about flood policies. Foresight studies are not an alternative to conventional planning that addresses specific projects over relatively short planning horizons. Rather, Foresight studies tend to address broader policy issues and more strategic policy decisions over longer planning horizons than conventional planning practice permits.

This Technical Note discusses planning and implementation of a regional-scale Foresight study to investigate flood and coastal erosion risks, their causes, their trends, and the strategies for managing those risks to achieve long-term policy objectives. The economic, social, and environmental consequences of flooding and coastal erosion in future years will be determined by decisions about where and how to build structures, what levels of flood protection are used in building flood defenses, what policies are employed regarding flood insurance, and numerous other such decisions that may be outside of the control of the flood manager as well as changes in public opinion and preferences. The Foresight study identifies the policy choices and other factors that may influence flood and coastal erosion risks, assesses the magnitude and direction of those effects, and ranks options to manage or mitigate those risks considering uncertainty in the socio-economic and climate conditions under which outcomes might be realized in the future. Results of the study should enable policy makers to assess alternatives for managing and mitigating flood and coastal erosion risks and to assess whether or not current policy is prudent with regard to maximizing the net benefits of flood and coastal erosion risk management over the long term.

The benefit of a Foresight study will be the knowledge and insights gained from systems-level thinking about flood and coastal erosion risk management. This knowledge and these insights will help decision makers to identify what policies and practices are likely to be the most effective in terms of mitigating future losses from flooding and coastal erosion. This information should enable policy makers to gauge whether or not current policy sets an effective course of action with regard to long-term risk management objectives. Information about the magnitude of future costs from flooding and coastal erosion may also enable state, local, and regional decision 
makers to place decisions about risk management policies and practices in perspective with respect to other needs in the study area.

The term "foresight" has been widely used for many years to describe strategic planning studies that attempt to identify and anticipate potential problems in the distant future, a field of study that is widely referred to as futures research. The body of futures research methods includes both quantitative and qualitative techniques (Gordon 1992). These methods have been employed to study problems in transportation, technology, energy, social science, public policy, public health, strategic planning, environmental scanning, and numerous other fields. The term "Foresight" also refers specifically to the United Kingdom (UK) government program to undertake such studies as a means of helping the government to think systematically about policy issues and their consequences over the long-term (e.g., 20-80 years) (BIS 2010). Foresight studies have been undertaken in the UK to study infectious diseases, infrastructure, addiction, cybercrime, cognitive systems, and flooding. Ongoing Foresight study projects are investigating issues in mental health, obesity, land use, food and agriculture, and climate change (BIS 2010). All Foresight studies make use of futures research methods, but each study employs those methods that are deemed best-suited for the particular problem of interest. There is no standard approach to conducting these types of studies. Investigators who are interested in implementing regional Foresight studies of flood and coastal erosion risks have a great deal of flexibility in choosing, developing, and adapting the methods described in this Technical Note.

This Technical Note is organized as follows. Section 2 describes the types of study questions that can be addressed using the Foresight study approach. Section 3 provides an overview of the steps involved in implementing the approach. Section 4 describes the identification and characterization of flood and coastal erosion risk drivers and risk responses. Section 5 describes the requirements of a suitable flood and coastal erosion risk model. Section 6 describes the use of experts and expert elicitation to overcome limitations in the ability to model risk drivers and risk responses. Section 7 describes the development and use of long-range planning scenarios. Section 8 proposes a phased implementation plan for a regional Foresight study.

WHAT KINDS OF QUESTIONS CAN A FORSIGHT STUDY ADDRESS? Foresight studies can be designed to address many different types of questions, but whatever the questions of interest, these should be made explicit at the beginning of the study because these will be important considerations in designing the study methods and outcomes. The questions addressed in the Foresight study will reflect necessarily the interests and concerns of those conducting the study. The following research questions are representative of those that might be raised in the course of a Foresight study to investigate flood and coastal erosion risks:

- What are the economic risks of flooding and coastal erosion in the region and how might these risks change over the next 50-100 years?

- What is the geographic distribution of economic risks from flooding and coastal erosion and how might the distribution of these risks change over the next 100 years?

- Are the risks of flooding and coastal erosion likely to change at different rates? 
- What societal risks (e.g., human exposure to contaminants, life-safety, mental health, socio-economic welfare) and environmental risks are associated with flooding and coastal erosion? How might these risks change over time?

- What are the primary factors that will influence trends in economic, social, and environmental risks? Which of these factors, called "drivers," will have the largest impact on these risks over the long-range planning horizon? How sensitive are these conclusions to key assumptions about what the future will be like?

- How important is climate change as a risk driver compared to other drivers?

- What policy responses might be most effective in terms of reducing future risks from flooding and coastal erosion? How cost effective are these various policy responses?

- What policy issues are raised through a critical review of these study results?

FORESIGHT STUDY APPROACH: The approach described in this Technical Note is based largely on that used in the Foresight Future Flood and Coastal Defence project, commissioned by the UK Office of Science and Technology (Evans et al. 2004, Thorne et al. 2007). The approach has also been used to study flood risk in the Taihu River Basin, China (Harvey et al. 2009). All Foresight studies make use of futures research methods, a large and diverse group of methods that include techniques such as scenario planning and expert elicitation. These techniques are used in conjunction with existing data, models, and forecasts to address the uncertainties and knowledge gaps that are associated with any long-range planning effort. For example, scenario planning involves constructing a handful of alternative plausible futures that explain how those futures might be realized. Once developed, existing models of flood and coastal erosion risk can be used in conjunction with these scenarios to respond to study questions.

In general, the steps required to implement a regional Foresight study can be summarized as follows:

- Identify risk drivers and risk responses. Risk drivers are phenomena such as climate change, urbanization, agricultural practices, environmental regulations, and other factors that can influence the frequency and severity of flood losses over time. Drivers are classified as risk sources, pathways, or receptors within the well-known source-pathwayreceptor risk assessment framework, a long-standing and widely used approach to conceptualizing human health and environmental risks. In this approach, the source is the physical cause of the hazard; the receptor is the object that is potentially harmed if exposed to the hazard, and the pathway is the route by which the receptor is exposed to the hazard. Risk responses are actions that may be taken to mitigate risk. Detailed descriptions of risk drivers and responses are written during the study. The identification and description of risk drivers and responses is based on expert judgment.

- Develop a quantitative risk assessment model. A risk assessment model is developed using the source-pathway-receptor framework to simulate flood and coastal erosion risks at an appropriate scale. The requirements of this risk assessment model and a representative list of input data needs are discussed in more detail below. The model should be 
developed with a resolution that is sufficient to simulate change in as many risk drivers and responses as possible or practical.

- Develop future scenarios. Scenarios that describe conditions under which flood and coastal erosion risks might be realized in the future are developed using a systematic approach such as that described in Ralston and Wilson (2006). It is important to remember that scenarios describe what might happen and are not predictions of what will happen. For example, the United Kingdom (UK) study used four scenarios that described how different political and cultural regimes might affect the locus of decision making authority (from local to international) and the importance of social values (individual vs. community). For a U.S. regional study, scenarios are likely to be considerably different from those used in the UK study.

- Assess future risks. The risk assessment model is updated to represent scenario conditions at a future point in time and risks are assessed while holding all prices at presentday levels. Future risk and the effects of risk drivers and responses are assessed as multipliers, which is the ratio of future risk to baseline risk. Planning horizons must be long enough to allow small changes over time to accumulate in meaningful ways and to capture that segment of the future that is not typically factored into today's risk management decisions. However, the longer the planning horizon is, the more speculative the analysis may become. Thus, there is an inherent trade-off that the study team must make.

- Assess how changes in risk drivers and responses affect risk. The risk assessment model is used to simulate the effect of changes in risk drivers and responses on changes in flood and coastal erosion risk. In the risk assessment model, each risk driver is represented by a native parameter that can be manipulated to simulate change. For example, if changes in agricultural land management practices will affect runoff rates from agricultural lands, the runoff rate can serve as a native parameter for changes in land management practices. There may be many risk drivers for which it is difficult to identify a convenient native parameter. In such cases, it may be possible to assess the effects using other methods. For example, the UK study used an expert elicitation approach to assess effects on risk when those effects could not be reasonably modeled.

- Assess uncertainty in risk estimates. Uncertainty is an inherent part of knowledge about large, complex natural systems that are driven and influenced by stochastic processes. Sources of uncertainty are identified and evaluated during a regional Foresight study. The implications of these uncertainties with respect to conclusions of the study are investigated by analyzing the sensitivity of study results, which are rankings of risk drivers and responses.

- Rank potential risk drivers and responses. Risk drivers and responses are ranked in terms of their ability to mitigate future flood and coastal erosion risk. Risk reduction effects are estimated under the assumptions of each planning scenario and independent rankings of risk responses are generated. The robustness of rankings under different assumptions about the future is assessed. Risk responses that rank consistently high 
across all scenarios are deemed most important because they are likely to have the most potential to reduce risk no matter how the future evolves.

RISK DRIVERS AND RISK RESPONSES: Risk drivers are phenomena that have the potential to alter the frequency or severity of losses from flooding and coastal erosion over time. Risk drivers used in the Foresight/UK study are listed in Table 1 as examples of the types of drivers that might be considered in a Foresight study. They include rainfall, temperature, urbanization, and land and water management practices. While it is expected that many of the same drivers will be applicable in any regional study, an independent assessment of what factors influence flood and coastal erosion risk should be part of the regional study process. Table 2 lists examples of native parameters that were used in the Foresight/UK study. Various native parameters may be more suitable for other regions. As with the selection of risk drivers, an independent assessment should be undertaken to identify the native parameters most suitable for the region of interest.

Source-pathway-receptor terminology is used to distinguish among the different components of a risk assessment model. In Table 1, each risk driver is identified as a source, pathway, or receptor. For example, source drivers that might affect flood and coastal erosion risk include precipitation and temperature. Changes in precipitation patterns over time can affect the rate and timing of peak river flows. Urbanization is an example of a pathway driver. Urbanization results in increased impervious surface area that tends to increase the rate of surface runoff and cause flashier river flows. As a driver, urbanization might also be classified as a receptor. Transitions from rural to urban land use tend to be associated with an increase in the concentration of wealth, resulting in an increase in the amount of property that is exposed to potential damage from flooding.

Risk responses are public and private actions undertaken to mitigate risk, and often involve actions that directly affect risk drivers. Some risk drivers are easier to exert control over than others. For example, it is very difficult to exert control over precipitation patterns and the frequency and severity of extreme tides. In contrast, it is relatively easy to build and maintain infrastructure to reduce the frequency of flood events and relatively easy to control land-use in floodplains to mitigate the potential consequences of flooding. The UK study found that the distinction between risk drivers and risk responses was not always clear. For example, while flood protection infrastructure may be built to reduce the frequency of flooding, its presence may affect the frequency of flooding in other parts of the system or encourage development and urbanization that increases the level of exposure.

FLOOD AND COASTAL EROSION RISK MODEL: A flood and coastal erosion risk model is needed to estimate the frequency and severity of damages from flooding and erosion. The model is used to simulate flood and coastal erosion risks under baseline conditions at the present time and under scenario conditions in the future. The systems-level model brings together disparate information about sources, pathways, and receptors to simulate the potential effect of alternative flood and coastal erosion risk responses. Table 3 presents a preliminary list showing what type of information would be required to develop a flood and coastal erosion risk assessment model for a Foresight study in the U.S. Source information includes data on sea levels and tides, waves, river flows, surface flow routing, and precipitation. Pathway data 


\begin{tabular}{|c|c|c|c|}
\hline \multicolumn{4}{|c|}{$\begin{array}{l}\text { Table 1. Examples of risk drivers that were considered in the UK Study (Evans et al., } \\
2004, \text { Table } 2.1 \text {, Volume I, p.35-37). Not all risk drivers mentioned here will be important } \\
\text { in a region and others that are not listed here may be of interest. }\end{array}$} \\
\hline Driver set & Driver & $\begin{array}{l}\text { S-P-R } \\
\text { Class }\end{array}$ & Driver Description \\
\hline \multirow[t]{2}{*}{$\begin{array}{l}\text { Climate } \\
\text { change }\end{array}$} & Precipitation & Source & $\begin{array}{l}\text { Changes in all aspects of precipitation (e.g., amount, duration, location, season- } \\
\text { ality, and clustering) }\end{array}$ \\
\hline & Temperature & Source & $\begin{array}{l}\text { Changes in ambient temperature and associated impacts (e.g., evapotranspi- } \\
\text { ration, soil moisture, surface runoff) }\end{array}$ \\
\hline \multirow{3}{*}{$\begin{array}{l}\text { Catchment } \\
\text { run-off }\end{array}$} & Urbanization & Pathway & Changes in impervious area and the extent of storm drainage \\
\hline & $\begin{array}{l}\text { Rural land } \\
\text { management }\end{array}$ & Pathway & $\begin{array}{l}\text { Effects of land management practices on managed lands including agricultural } \\
\text { areas, conservation/recreation areas, and wetlands }\end{array}$ \\
\hline & Agricultural impacts & Receptor & $\begin{array}{l}\text { Impact of flooding and associated high water tables on farm and forestry land } \\
\text { and associated managed habitats }\end{array}$ \\
\hline \multirow[t]{3}{*}{$\begin{array}{l}\text { Fluvial } \\
\text { processes }\end{array}$} & $\begin{array}{l}\text { Environmental } \\
\text { regulation }\end{array}$ & Pathway & $\begin{array}{l}\text { Future legislation intended to increase biodiversity and habitat protection that } \\
\text { may influence policy on flood management with implications for river and flood- } \\
\text { plain morphology, vegetation, conveyance, and flood storage. }\end{array}$ \\
\hline & $\begin{array}{l}\text { River morphology } \\
\text { and sediment supply }\end{array}$ & Pathway & $\begin{array}{l}\text { Changes in morphology (channel size, shape, floodplain topography) and } \\
\text { sediment supply that alter attributes of the river channel and floodplain to } \\
\text { influence routing, and conveyance, and storage (e.g., channelization). }\end{array}$ \\
\hline & $\begin{array}{l}\text { River vegetation and } \\
\text { conveyance }\end{array}$ & Pathway & $\begin{array}{l}\text { Vegetation and micro-morphology may affect velocity and turbulence, affecting } \\
\text { the downstream migration of flood waters. }\end{array}$ \\
\hline \multirow[t]{4}{*}{$\begin{array}{l}\text { Coastal } \\
\text { processes }\end{array}$} & Waves & Source & $\begin{array}{l}\text { Changes in wave height and direction (caused by changes in climate, for exam- } \\
\text { ple) may affect wave energy to the shoreline. }\end{array}$ \\
\hline & $\begin{array}{l}\text { Relative sea level } \\
\text { rise }\end{array}$ & Source & Changes in sea-level can affect the frequency and severity of coastal floods. \\
\hline & Storm surge & Source & $\begin{array}{l}\text { Changes in sea-level that result from low barometric pressure during coastal } \\
\text { storms. A change in the severity of storms could affect storm surge elevations } \\
\text { and coastal erosion processes. }\end{array}$ \\
\hline & $\begin{array}{l}\text { Coastal morphology } \\
\text { and sediment supply }\end{array}$ & Pathway & $\begin{array}{l}\text { Changes in near shore bathymetry, shoreline, and adjacent coastal land can } \\
\text { alter the patterns of coastal erosion and affect storm surge elevations. }\end{array}$ \\
\hline \multirow[t]{2}{*}{$\begin{array}{l}\text { Human } \\
\text { behavior }\end{array}$} & $\begin{array}{l}\text { Stakeholder } \\
\text { behavior }\end{array}$ & Pathway & $\begin{array}{l}\text { Changes in behavior (ranging from pre-flood preparedness to post-disaster self- } \\
\text { help) can affect risk, as can seemingly unrelated decisions corporate and } \\
\text { government stakeholders. Changes in stakeholder behavior will be strongly } \\
\text { linked to trends in societal values. }\end{array}$ \\
\hline & $\begin{array}{l}\text { Public attitudes and } \\
\text { expectations } \\
\text { (indirect) }\end{array}$ & Receptor & $\begin{array}{l}\text { Determines preferences for styles of risk management. This driver acts primarily } \\
\text { through stakeholder behavior. }\end{array}$ \\
\hline \multirow[t]{5}{*}{$\begin{array}{l}\text { Socio- } \\
\text { economics }\end{array}$} & $\begin{array}{l}\text { Buildings and } \\
\text { contents }\end{array}$ & Receptor & $\begin{array}{l}\text { The damage to buildings and their contents, including damage to production } \\
\text { and household durables, as well as raw materials, intermediate goods and } \\
\text { consumer goods. }\end{array}$ \\
\hline & Urban impacts & Receptor & $\begin{array}{l}\text { Type and layout of buildings and resulting densities of development, building } \\
\text { form, and nature of land use, all affect the magnitude of flood losses per unit } \\
\text { area. }\end{array}$ \\
\hline & $\begin{array}{l}\text { Infrastructure } \\
\text { impacts }\end{array}$ & Receptor & $\begin{array}{l}\text { The networks of services that enable the economy to transform raw materials } \\
\text { into goods, intermediate goods, and final consumption. Floods indirectly affect } \\
\text { areas outside the flooded area via networks. }\end{array}$ \\
\hline & Social impacts & Receptor & Life, safety, physical and mental health impacts, community cohesion. \\
\hline & $\begin{array}{l}\text { Science and } \\
\text { Technology (indirect) }\end{array}$ & Receptor & $\begin{array}{l}\text { Determine the ratio of economic output to input of labor, capital, and resources. } \\
\text { Indirect driver influences flood and coastal erosion risk via buildings, contents, } \\
\text { urban impacts, and infrastructure drivers. }\end{array}$ \\
\hline
\end{tabular}




\begin{tabular}{|c|c|}
\hline Risk Driver & Native Parameters \\
\hline Precipitation & Annual and seasonal rainfall amounts. \\
\hline Temperature & Average annual and seasonal temperatures, temperature effects on rainfall and evaporation. \\
\hline Urbanization & $\begin{array}{l}\text { Proportion of each catchment area classified as urban land use. Prevalence of stormwater manage- } \\
\text { ment practices. }\end{array}$ \\
\hline Rural land management & $\begin{array}{l}\text { Rates of surface runoff reflecting changes in land management practices on agricultural lands and in } \\
\text { conservation and recreation areas. }\end{array}$ \\
\hline Agricultural impacts & The value of crops that would be damaged in a flood event of a designated severity. \\
\hline $\begin{array}{l}\text { Environmental } \\
\text { regulation }\end{array}$ & $\begin{array}{l}\text { Standard of flood protection is adjusted to reflect changes in environmental flow requirements and land } \\
\text { management requirements to reduce surface runoff. }\end{array}$ \\
\hline $\begin{array}{l}\text { River morphology and } \\
\text { sediment supply }\end{array}$ & $\begin{array}{l}\text { Channel width and river depth. Increases in width suggest erosion that may weaken flood defenses and } \\
\text { increases in river depth suggest increases in channel capacity. }\end{array}$ \\
\hline $\begin{array}{l}\text { River vegetation and } \\
\text { water conveyance }\end{array}$ & The level of flood protection is adjusted to reflect changes in water conveyance. \\
\hline Waves & No native parameter is identified. \\
\hline Relative sea level rise & Mean sea level. \\
\hline Storm surge & Return period for tidal elevations. \\
\hline $\begin{array}{l}\text { Coastal morphology } \\
\text { and sediment supply }\end{array}$ & $\begin{array}{l}\text { Coastline form. Creation, movement, or removal of channels and banks. Position of the foreshore. } \\
\text { Position of coastal features such as cliffs and headlands. }\end{array}$ \\
\hline Stakeholder behavior & No native parameter is identified. \\
\hline $\begin{array}{l}\text { Public attitudes and } \\
\text { expectations (indirect) }\end{array}$ & Actual flood and coastal erosion risk. \\
\hline Buildings and contents & Proportion of urban areas located in flood plains. \\
\hline Urban impacts & $\begin{array}{l}\text { Proportion of flood plain area that is urbanized. Urban area subject to flooding greater than two feet } \\
\text { deep. Annual percent change in value of building stock. Floor area (intensity of building development). } \\
\text { Potential for release of hazardous materials to the environment. }\end{array}$ \\
\hline Infrastructure impacts & No native parameter is identified. \\
\hline Social impacts & An ad-hoc index of social flood vulnerability. \\
\hline $\begin{array}{l}\text { Science and technology } \\
\text { (indirect) }\end{array}$ & No native parameter is identified. \\
\hline
\end{tabular}

includes information on topography, hydrography (location of rivers and coastlines), bathymetry, flood zones, and flood infrastructure (location, level of protection, and condition). Receptor information includes data on objects that might be damaged by flooding, including structures, vehicles, people, and crops. Depth damage functions are used to assess the severity of damages that result from flooding. Wherever possible, native parameters should be incorporated within the model to facilitate the simulation of risks in the future and the simulation of risk responses.

Much of the information required to develop a risk assessment model is available for most of the United States in some form or another. The challenge for regional studies is to bring these disparate sources of information together at an appropriate scale and in such a way that many different risk drivers and policy responses can be simulated using a single model. Examples of such models that might be adapted for Foresight studies in the U.S. include the Flood Damage Analysis (FDA) software developed by the Hydrological Engineering Center (HEC-FDA) (USACE 2008) and HAZUS-MH, developed by FEMA (FEMA 2010). 


\begin{tabular}{|c|c|c|}
\hline \multicolumn{3}{|c|}{$\begin{array}{l}\text { Table } 3 . \text { A preliminary list of input data requirements for a flood and coastal erosion } \\
\text { risk assessment model that would be appropriate for a Foresight study. }\end{array}$} \\
\hline Class & Data & Description \\
\hline \multirow[t]{7}{*}{ Source } & $\begin{array}{l}\text { Sea levels and } \\
\text { tides }\end{array}$ & Historic data (30 years) or reports on sea level and extremes. \\
\hline & Waves & Historic data on waves and/or any reports describing extreme waves \\
\hline & Fluvial hydrology & Daily data on river flows from local gage stations. \\
\hline & Watersheds & Hydrologic unit classification (HUC) boundaries (12-digit). \\
\hline & $\begin{array}{l}\text { Surface flow } \\
\text { routing }\end{array}$ & The direction of surface water flows in grids. \\
\hline & Precipitation & Historic data (30 years) on daily rainfall at local monitoring stations \\
\hline & Trends & Trends in sea level, location of coastline, frequency and intensity of storms, rainfall, etc. \\
\hline \multirow[t]{6}{*}{ Pathway } & Hydrography & Polyline of the river network showing river centerline or river banks. \\
\hline & Coastline & Polyline showing the limits of high and low tides. \\
\hline & $\begin{array}{l}\text { Foreshore levels } \\
\text { and slopes }\end{array}$ & $\begin{array}{l}\text { Bathymetry or general slope descriptors. Changes in ocean bathymetry and trends or patterns of } \\
\text { change over time. }\end{array}$ \\
\hline & Geology & $\begin{array}{l}\text { Coastal and non-coastal geology as relevant to long-term prediction of changes in coastline, } \\
\text { surface water infiltration, etc. Coastal erosion rates. }\end{array}$ \\
\hline & $\begin{array}{l}\text { Coastal flood } \\
\text { defenses }\end{array}$ & $\begin{array}{l}\text { Existing flood defenses (location, type (e.g., beach, sheet pile wall), crest elevation and width } \\
\text { (wide or narrow), condition, photographs (geo-referenced), front and rear slopes, construction } \\
\text { details (if available), geometry (if available), and survey information or reports (if available). }\end{array}$ \\
\hline & $\begin{array}{l}\text { Digital terrain } \\
\text { model (DTM) }\end{array}$ & Topography of the floodplain \\
\hline \multirow[t]{4}{*}{ Receptor } & Real estate & $\begin{array}{l}\text { Location of structures (point or polygon), type of structures (e.g., commercial/residential, single } \\
\text { family, multi-family, number of stories), building characteristics, property values, first floor eleva- } \\
\text { tions, flood-proofing practices, etc. }\end{array}$ \\
\hline & Demographics & $\begin{array}{l}\text { Population, residential occupancy rates, number of people per household, (per household), popu- } \\
\text { lation characteristics by census block or block group. }\end{array}$ \\
\hline & Environment & Land cover classification, impervious area, vegetation and habitat type. \\
\hline & Other & $\begin{array}{l}\text { Existing reports and data relating to ongoing activities in the study area including any flood and } \\
\text { coastal erosion risk analyses, derivation of flood extents, climate change impact studies, and local } \\
\text { development planning studies. }\end{array}$ \\
\hline
\end{tabular}

The risk assessment model must be structured in a manner that is suitable for addressing the particular set of questions raised in a regional Foresight study. The systems-level flood-risk assessment model used in the Foresight/UK study illustrates what types of capabilities these might include (Hall et al. 2003, Sayers and Meadowcroft 2005, Gouldby et al. 2008). The model provides a probabilistic representation of the source, pathway and receptor components and includes extreme value distributions for water levels at each reach of the flood protection system (including coastal reaches), fragility curves for components of the flood protection system, and a hydraulic flood spreading model to represent the propagation of floodwater across floodplains. It incorporates data on property, people, and crops as well as stage-damage functions relating flood stage to the severity of flood consequences. The model domain is resolved into discrete flood areas that are assumed to be hydraulically independent. Boundaries of flood areas are typically formed from topographic features, such as high ground and river channels. The flood protection infrastructure forms a boundary between the river channel and the adjacent floodplain. Components of the flood protection infrastructure have varying resistance to hydraulic loads depending upon condition and geometry. The performance of various flood protection system components is assumed to be independent of one another. The model used in the Foresight/UK study serves here to demonstrate what kinds of features might be needed in a risk assessment model. 
However, regional Foresight studies in the U.S. may require different features. Data formats and datasets may also suggest a somewhat different approach. The decision regarding what model to use needs to be made on a case-by-case basis for each regional study.

The primary output of the Foresight study is a ranking of risk drivers and risk responses so that the most effective risk mitigation strategies can be identified given the range of possible futures that are anticipated. The effects of changes in risk drivers and responses are quantified using the risk assessment model by altering conditions in the model. For example, changes in climate can be simulated by changing sea-levels, evaporation rates, and rainfall amounts. Restrictions on future land use can be simulated by altering the location of future development. Investments to raise the level of protection can be simulated by increasing the crest elevation of flood defenses. Changes in river channel management can be simulated by adjusting conveyance capacity. Temporary flood fighting measures to protect certain structures might be simulated by adjusting depth-damage curves used in the model. Non-structural risk responses that address flood preparedness, emergency response planning, forecasting, and building codes can also be simulated. Methods used during Foresight/UK to represent these changes in the risk assessment model are outlined in Table 4.

\begin{tabular}{|c|c|c|}
\hline Risk Driver & Brief description & Representation in risk model \\
\hline Rainfall & $\begin{array}{l}\text { Changing rainfall intensity, duration and seasonality due to } \\
\text { climate change }\end{array}$ & Rainfall input time series \\
\hline Upland catchment change & $\begin{array}{l}\text { The effect of changed rates of runoff, due to construction of } \\
\text { reservoirs, changes in reservoir control rules and land use } \\
\text { change }\end{array}$ & $\begin{array}{l}\text { Parameterization of rainfall-runoff } \\
\text { model }\end{array}$ \\
\hline Mean sea level rise & Increasing mean sea level due to climate change & $\begin{array}{l}\text { Shift in tidal boundary to drainage } \\
\text { system }\end{array}$ \\
\hline $\begin{array}{l}\text { Urbanization (pathway } \\
\text { impacts) }\end{array}$ & $\begin{array}{l}\text { Construction of ring-dyke/ pumping systems and blocking or } \\
\text { filling of drainage channels accompanying urbanization }\end{array}$ & $\begin{array}{l}\text { Changing storage and conveyance in } \\
\text { developed areas }\end{array}$ \\
\hline Subsidence & Local and regional land lowering & $\begin{array}{l}\text { Changes in digital elevation model } \\
\text { land elevations }\end{array}$ \\
\hline Land use (receptors) & $\begin{array}{l}\text { Increasing urban land cover leading to increasing exposure } \\
\text { to flood risk }\end{array}$ & $\begin{array}{l}\text { Change in urban area in damage } \\
\text { assessment }\end{array}$ \\
\hline $\begin{array}{l}\text { Value of building contents } \\
\text { and economic activity }\end{array}$ & Increasing value of buildings and industry in the floodplain & Change in depth damage functions \\
\hline Risk Response & Brief description & Representation in risk model \\
\hline $\begin{array}{l}\text { Channel discharge } \\
\text { capacity }\end{array}$ & Increasing cross-section of primary channels. & Aggregated scaling of conveyance \\
\hline $\begin{array}{l}\text { Construction of new } \\
\text { channels }\end{array}$ & Construction of new channels & $\begin{array}{l}\text { Implementation of specific new } \\
\text { channels }\end{array}$ \\
\hline Pump capacity & Increasing pump capacity & Aggregate pump capacity \\
\hline $\begin{array}{l}\text { Construction of secondary } \\
\text { dike rings }\end{array}$ & $\begin{array}{l}\text { Cities constructing dike rings to provide enhanced standard } \\
\text { of protection and urban drainage. }\end{array}$ & $\begin{array}{l}\text { Introduction of new dike rings and } \\
\text { pumps }\end{array}$ \\
\hline Gates and barriers & Construction of major new flood control gates and barriers & $\begin{array}{l}\text { Installation of gates/barriers in } \\
\text { hydraulic model }\end{array}$ \\
\hline Dike levels & Increasing dike crest levels & Aggregate increase in dike crest levels \\
\hline Land use planning & Control of urbanization in the floodplain & \begin{tabular}{|l|} 
Change in floodplain land cover \\
(projected urbanization is constrained)
\end{tabular} \\
\hline Flood fighting & Emergency measures to repair dikes and breaches & $\begin{array}{l}\text { Change in probability of failure and } \\
\text { duration for which breach is open }\end{array}$ \\
\hline
\end{tabular}


USE OF EXPERTS AND EXPERT ELICITATION: Experts provide the comprehensive knowledge and understanding of the climatic, hydrologic, and social systems and their interactions to develop a quantitative risk assessment model. As discussed above, this model is used to evaluate multipliers for risk drivers and risk responses. However, the questions addressed in a Foresight study are highly complex and any quantitative risk assessment model will have limitations in terms of its ability to represent changes in risk drivers and responses. The limitations of a quantitative risk assessment model may arise for several reasons, including: 1) the availability or resolution of input data about the system; 2) the ability to represent processes mathematically; 3 ) the understanding of the system; or 4) the time and money available for the study. When confronted by study questions that exceed the limits of the quantitative risk assessment model, expert elicitation may be considered as a strategy to address study questions.

Because of the complexity of the issues involved, experts and expert knowledge will typically play an important role in a regional Foresight study. Expert elicitation describes any structured approach to interviewing experts and tapping their knowledge. Relevant experts include those from the disciplines of engineering, climatology, socio-economics, geomorphology (fluvial/coastal), hydrology, water resources management, ecology, environment, and planning (urban and rural). Developing an expert elicitation protocol that meets the requirements of a scientifically defensible method, meaning that it is replicable, verifiable, and peer reviewed, can present a challenge. Expert elicitation protocols must be developed to identify and characterize each risk driver and risk response and then assess multipliers for those risk drivers and risk responses. Experts will assess multipliers for all risk drivers and risk responses, including those that can be assessed using the risk assessment model. Risk multipliers obtained through expert elicitation are compared with those obtained through modeling to confirm expert elicitation results.

Methods of expert elicitation have been discussed by numerous authors including Morgan and Henrion (1990) and Ayyub (2000). The particular expert elicitation protocol used in the Foresight/UK study, described in Thorne et al. (2007), might be adapted for regional studies in the U.S. Risk drivers and risk responses were identified in a brain-storming session and grouped into a manageable number of sub-groups based on mechanisms by which they affect flood risk, interactions with other drivers and responses, and constraints on future changes in drivers. Future change in each driver was described and, where possible, change in each driver was quantified using evidence from the literature. Drivers were ranked according to an expert assessment of their impact on total flood risk over 50 and 80-year time frames under conditions represented by each of the four scenarios. A multiplier was assessed for each driver and response and was weighted by the spatial extent of the influence. The multiplier is the ratio of the predicted future probability or consequence and the present-day probability or consequence, depending upon whether the drivers operated on sources and pathways or receptors (i.e., probabilities were used for drivers that operated on sources and pathways and consequences were used for drivers that operated on receptors). Fifteen experts participated in the elicitation of multipliers. Elicitation began with each expert independently assessing a multiplier for each driver within his domain of expertise. This was followed by group discussion during which multipliers were amended, and for those drivers that could be modeled using the risk assessment model, compared with risk model outputs. Peer review of the results occurred through invitation-only workshops, a public stakeholder meeting, and electronic publication. Whatever elicitation protocol is used, it should 
be thoroughly reviewed and tested prior to implementation to document its validity and ensure replicable and meaningful results.

LONG-RANGE PLANNING SCENARIOS: There is a great deal of uncertainty in projecting flood risks over many years and developing a risk reduction strategy. Scenarios are a recognized technique for strategic planning in the face of poorly characterized uncertainty (Ralston and Wilson 2006). The idea behind scenario planning is to imagine a relatively small set of possible futures so that the robustness of study conclusions can be tested in the face of uncertainty about that future. A scenario is a relatively detailed and coherent description of a potential future, not a forecast of what will occur. While scenarios are often developed based on a realistic assessment of future trends, they are also infused with a large amount of expert judgment. Collectively, scenarios should capture the range of possible futures. Scenarios are translated into parameters in the risk assessment model to simulate future risks.

In the Foresight/UK study, four scenarios were developed by considering how society and the world might evolve in terms of governance and societal values. ${ }^{1}$ The scenarios are illustrated in Figure 1. Governance refers to the locus of decision making authority. The governance spectrum ranges from "autonomy," which describes a condition in which power remains at the local and national levels, to "interdependence," which describes a condition in which power is concentrated in international institutions. In the Foresight/UK scenarios, future trends in climate-related source variables (e.g., risk drivers such as sea-level rise and precipitation) depend upon global greenhouse gas emissions, which in turn depend upon where decision making authority is located on the governance spectrum. The societal values spectrum describes the context in which flood management policy and practice will be enacted and relates to the extent to which flooding may affect society (e.g., how the costs of flooding and coastal erosion will be distributed in society). The values spectrum ranged from "consumerist" to "community-oriented."

Each scenario represents a condition under which development over the planning horizon might occur. For example, the combination of a consumerist oriented value system and an interdependent governance system leads to a "World Markets" scenario which - in the judgment of the expert panel used on the UK study team - leads to certain outcomes such as a rate of carbon emissions and a high rate of change in some of the climate-related risk drivers such as sea-level rise. The implications of a World Markets scenario extend far beyond climate-related risk drivers. The scenario affects social and economic risk drivers as well. For example, the prevalence of insurance, who bears the costs of flood and coastal erosion losses, and who makes decisions about where development can occur.

The UK study results showed that it was important to consider shifts in governance and socioeconomic values jointly. While climate change will tend to affect the flood frequencies, socioeconomic factors will largely determine the cost of the resulting damage. Both are needed to provide a complete picture of future flood and coastal erosion risk and to identify the most important responses to reduce risk. Whether or not the Foresight/UK scenarios are the most

\footnotetext{
${ }^{1}$ The climate change scenarios were based on the report of the UK Climate Impacts Programme, UKCIP02 (Hulme et al. 2002) and the socio-economic scenarios were taken from work done by the Social Policy Research Unit, University of York, which was based on the Intergovernmental Panel on Climate Change (IPCC) Special Reports on Emission (SRES) scenarios.
} 
appropriate scenarios for a regional Foresight study in the United States has yet to be determined. However, it is likely that a regional Foresight study will require an effort to construct a set of scenarios that is appropriate to the location of the region considering the problems and interests of regional stakeholders.

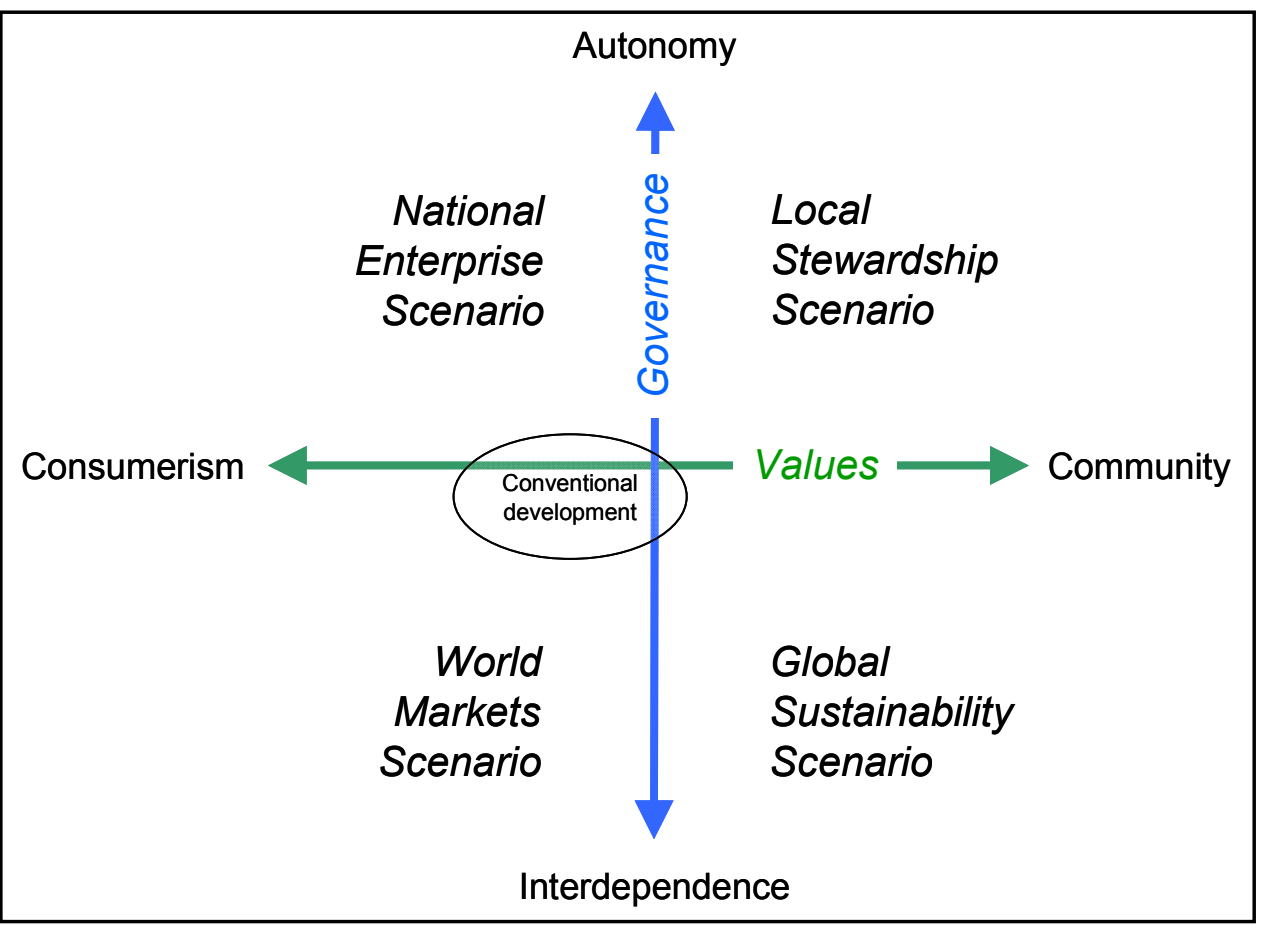

Figure 1. Long-range planning scenarios used in Foresight/UK (from Evans et al., 2004).

PHASED IMPLEMENTATION PLAN: Prior to initiating a regional Foresight study, it will be necessary to develop a project management plan (PMP). The PMP will describe management and oversight of the project, task and activity breakdown, schedule, and budgets. The PMP should also identify stakeholders and experts who are willing to participate in this study. Because of the importance of expert elicitation in Foresight, a suitable expert elicitation protocol should be proposed and outlined in the PMP before initiating the study. If possible, this expert elicitation protocol should be peer reviewed. During the Foresight study, experts will advise on all aspects of regional flood and coastal erosion risk assessment, including the identification and description of risk drivers and risk responses and the assessment of multipliers. This group of experts should include individuals from disciplines of engineering, climatology, socio-economics, geomorphology (fluvial/coastal), hydrology and water resources, environment and ecology, and planning (urban and rural).

A phased plan for implementation of a regional Foresight study is outlined in Table 5. This plan outlines, in general terms, how Foresight could be implemented in three phases and describes the tangible outputs from each phase of work. The principal goal during Phase 1 is to develop a risk assessment model, assess baseline risks, develop planning scenarios, and, if not already completed, further refine the proposed expert elicitation protocol. A quantitative risk model will 


\section{Table 5. Task descriptions and outputs that are broadly applicable to regional Foresight studies.}

\begin{tabular}{|c|c|c|}
\hline Task & Description & Outputs \\
\hline \multicolumn{3}{|c|}{ 1.0 Assess Baseline Risks and Formulate Planning Scenarios } \\
\hline \multirow[t]{2}{*}{1.1} & \multirow{2}{*}{$\begin{array}{l}\text { Establish future scenarios for long-range planning that address } \\
\text { climate change and socio-economic change. }\end{array}$} & Scenario descriptions for long-range planning. \\
\hline & & $\begin{array}{l}\text { A list of native parameters and their potential values to } \\
\text { represent differences among scenarios. }\end{array}$ \\
\hline \multirow[t]{3}{*}{1.2} & \multirow{3}{*}{$\begin{array}{l}\text { Develop a quantitative risk assessment model using the } \\
\text { source-pathway-receptor framework and apply the model to } \\
\text { estimate present-day risks. }\end{array}$} & A flood and coastal erosion risk assessment model \\
\hline & & $\begin{array}{l}\text { A simulation of present-day flood and coastal erosion } \\
\text { risk. }\end{array}$ \\
\hline & & $\begin{array}{l}\text { A map showing the geographical distribution of flood and } \\
\text { coastal erosion risks. }\end{array}$ \\
\hline 1.3 & Develop an expert elicitation protocol. & An expert elicitation protocol for Phases II and III \\
\hline 1.4 & Report on the methods and findings from Phase 1. & Report. \\
\hline 1.5 & Stakeholder meeting(s). & $\begin{array}{l}\text { Comments on Phase } 1 \text { outputs and a list of proposed risk } \\
\text { drivers for use in Phase } 2 \text {. }\end{array}$ \\
\hline \multicolumn{3}{|c|}{ 2.0 Assess Future Risks and Multipliers for Risk Drivers } \\
\hline \multirow[t]{4}{*}{2.1} & \multirow{4}{*}{$\begin{array}{l}\text { Expert elicitation - List risk drivers, develop detailed driver } \\
\text { descriptions, and assess risk multipliers. }\end{array}$} & A list of risk drivers by functional group. \\
\hline & & Descriptions of risk drivers and their interactions. \\
\hline & & Identify native parameters and quantify changes. \\
\hline & & Preliminary estimates of risk multipliers. \\
\hline \multirow[t]{2}{*}{2.2} & \multirow{2}{*}{$\begin{array}{l}\text { Risk modeling - Simulate future risks using the source- } \\
\text { pathway-receptor risk assessment model and assess risk } \\
\text { multipliers. }\end{array}$} & $\begin{array}{l}\text { Translate native parameter changes into changes in } \\
\text { model parameters and their distributions. }\end{array}$ \\
\hline & & $\begin{array}{l}\text { Risk multipliers based on quantitative risk assessment } \\
\text { model. }\end{array}$ \\
\hline \multirow[t]{2}{*}{2.3} & \multirow{2}{*}{$\begin{array}{l}\text { Validation - Compare risk multipliers obtained through expert } \\
\text { elicitation and modeling. }\end{array}$} & Rank risk drivers in terms of risk multipliers. \\
\hline & & Validation of simulation results. \\
\hline 2.4 & Report on the methods and findings from Phase 2. & Report \\
\hline 2.5 & Stakeholder meeting(s) & $\begin{array}{l}\text { Comments on Phase } 2 \text { outputs and a list of proposed risk } \\
\text { responses for use in Phase } 3 .\end{array}$ \\
\hline \multicolumn{3}{|c|}{ 3.0 Assess Multipliers for Risk Responses } \\
\hline \multirow[t]{4}{*}{3.1} & \multirow{4}{*}{$\begin{array}{l}\text { Expert elicitation - List of risk responses, develop detailed } \\
\text { descriptions of risk responses, and assess multipliers for risk } \\
\text { responses. }\end{array}$} & A list of risk responses by functional group. \\
\hline & & Descriptions of risk responses and interactions. \\
\hline & & Identify native parameters and quantify changes. \\
\hline & & Preliminary estimates of risk multipliers. \\
\hline \multirow[t]{2}{*}{3.2} & \multirow{2}{*}{$\begin{array}{l}\text { Risk modeling - Simulate risk responses using the source- } \\
\text { pathway-receptor risk assessment model and assess risk } \\
\text { multipliers. }\end{array}$} & $\begin{array}{l}\text { Translate native parameter changes into changes in } \\
\text { model parameters and their distributions. }\end{array}$ \\
\hline & & $\begin{array}{l}\text { Risk multipliers based on quantitative risk assessment } \\
\text { model. }\end{array}$ \\
\hline 3.3 & $\begin{array}{l}\text { Validation - Compare risk multipliers obtained through expert } \\
\text { elicitation and modeling. }\end{array}$ & $\begin{array}{l}\text { Rank risk responses in terms of risk multipliers. } \\
\text { Validation of simulation results }\end{array}$ \\
\hline 3.4 & $\begin{array}{l}\text { Benefit-cost analysis - Estimate the costs and benefits of risk } \\
\text { responses and benefit-cost ratios considering monetizable and } \\
\text { non-monetizable (e.g., environmental, other social effects, } \\
\text { human health) benefits and costs. }\end{array}$ & Ranking of risk responses in terms of cost effectiveness. \\
\hline 3.5 & Report on the methods and findings from Phase 3. & Report \\
\hline
\end{tabular}

be developed that is similar to that described above. Baseline flood and coastal erosion risks will be simulated using this quantitative risk assessment model. Planning scenarios similar to those discussed above will also be developed during this phase. The outputs of Phase 1 are the scenarios and their descriptions and an expert elicitation protocol along with a simulation of baseline 
(present-day) flood and coastal erosion risks and a map showing the geographic distribution of those risks in the region of interest. Between Phases 1 and 2, the stakeholders should be engaged to provide comments on the Phase 1 work. Stakeholders should also identify a list of risk drivers, noting that the project's cadre of experts will be free to create their own list of drivers for use in Phase 2.

During Phase 2, the goal is to identify and describe risk drivers and assess risk multipliers for each driver. Experts will identify risk drivers and native parameters, organize them into functional groups, and write detailed descriptions of each driver. Expert elicitation techniques will then be employed to assess how the native parameter(s) for each risk driver is likely to change over time and under each scenario. Experts will also make preliminary assessments of risk multipliers to assess how strongly the risk drivers may affect flood and coastal erosion risk. Periodic meetings of experts will be needed during Phase 2 to build consensus. The quantitative risk model will be used to simulate flood and coastal erosion risks in the future at agreed upon intervals of time (e.g., 50, 80, 100 years hence) for each planning scenario. The geographic distribution of future risks should be mapped and risk multipliers for each risk driver should be estimated using the risk assessment model. Risk multipliers estimated using the model will be compared with those obtained from expert elicitation as a means of validating simulation results. Discrepancies between multipliers estimated using the model and those obtained through expert elicitation should be resolved. Risk drivers should then be ranked for each planning scenario based on the risk multipliers. Between Phase 2 and Phase 3, stakeholders will comment on the results from Phase 2 and suggest a list of risk responses to be considered in Phase 3, along with suggesting ways of assessing those risk responses.

During Phase 3, the necessary tasks include identifying and describing risk responses and their native parameters and assessing risk multipliers for each risk response through expert elicitation and the risk assessment model. Experts should identify risk responses and native parameters, organize them into functional groups, and write detailed descriptions of each response. Expert elicitation techniques will then be employed to assess how the native parameter(s) for each risk response is likely to change over time and under each scenario. Experts will make preliminary assessments of risk multipliers to assess how strongly the risk response may affect flood and coastal erosion risk. Experts should meet periodically during Phase 3 to resolve differences in opinion and build consensus around the results and conclusion of the study. Risk multipliers for each risk response should be estimated using the risk assessment model and compared with those obtained from expert elicitation as a means of validating simulation results. Any discrepancies between multipliers estimated using the model and obtained through expert elicitation should be resolved. Risk responses should be ranked for each scenario based on the risk multipliers. The cost of each risk response should be estimated and a benefit-cost ratio should be calculated considering both monetary and non-monetary outcomes (e.g., human health, environmental, other social effects). Risk responses are then ranked based on their cost effectiveness. Results of the Foresight study should be described in a report summarizing the study methods and conclusions. The report should contain information on the magnitude of future flood and coastal erosion risk, the distribution of those risks, and the relative importance of risk drivers.

CONCLUSIONS: This CHETN offers general information to assist in planning regional Foresight studies to assess future flood and coastal erosion risks and risk management strategies. The CHETN includes information on what types of questions might be addressed through a Foresight 
study, how these questions might be approached using simulation models and expert elicitation techniques, and how a regional Foresight study might be implemented in a phased approach. However, there are no hard and fast rules for conducting Foresight studies. Each regional Foresight study will be motivated by a set of concerns that are unique to the region of interest. Therefore, the regional study team should adapt the information provided in this CHETN as necessary to satisfy the specific requirements of the region and problem of interest.

ADDITIONAL INFORMATION: For additional information contact William R. Curtis, Coastal and Hydraulics Laboratory, U.S. Army Engineer Research and Development Center, 3909 Halls Ferry Road, Vicksburg, MS 39180 at (601) 634-3040, or e-mail William.R.Curtis@usace.army. mil. This effort was funded through the Flood and Coastal Storm Damage Reduction Research and Development Program. Program Manager is William R. Curtis.

This Technical Note should be cited as follows:

Schultz, M. T., S. E. Durden, P. Sayers, B. P. Gouldby, J. D. Simm, W. R. Curtis, and J. E. Davis. 2011. Planning regional flood and coastal erosion foresight studies. Coastal and Hydraulics Engineering Technical Note ERDC/CHL CHETN-II-53. Vicksburg, MS: U.S. Army Engineer Research and Development Center. http://chl.erdc. usace.army.mil/chetn.

\section{REFERENCES}

Ayyub, B. M. 2000. Methods for Expert Opinion Elicitation of Probabilities and Consequences for Corps Facilities. Institute for Water Resources Report 00-R-10, U.S. Army Corps of Engineers, Alexandria, VA. p.120.

Department of Business, Innovation, and Skills (BIS). 2010. Foresight studies website. http://www.bis.gov.uk/ foresight Accessed Sept. 26, 2010.

Evans, E., R. Ashley, J. Hall, E. Penning-Rowsell, A. Saul, P. Sayers, C. Thorne, and A. Watkinson. 2004. Foresight. Future flooding. Scientific Summary: Volume 1 - Future Risks and Their Drivers, Office of Science and Technology, London.

Federal Emergency Management Agency (FEMA). 2010. HAZUS®MH MR3 Technical Manual, Department of Homeland Security, Federal Emergency Management Agency, Mitigation Division, Washington, DC.

Gordon, T. J. 1992. The Future: Trends into the Twenty-First Century, Annals of the American Academy of Political and Social Science 522(1992): 25-35.

Gouldby, B., P. Sayers, J. Mulet-Marti, M.A.A.M. Hassan, and D. Benwell. 2008. A methodology for regional scale flood and coastal erosion risk assessment, Proceedings of the Institute for Civil Engineers - Water Management, June 2008.

Hall, J. W., R. J. Dawson, P. B. Sayers, C. Rosu, J. B. Chatterton, and R. Deakin. 2003. A methodology for national scale flood and coastal erosion risk assessment, Proceedings of the Institute for Civil Engineers - Water and Maritime Engineering, 156(3):235-247.

Harvey, G. L., C. R. Thorne, X. Cheng, E. P. Evans, S. Han, J. D. Simm, and Y. Wang. 2009. Qualitative analysis of future flood risk in the Taihu Basin, China, Journal of Flood Risk Management 2(2009): 85-100.

Hulme, M., G. Jenkins, X. Lu, J. Turnpenny, T. Mitchell, R. Jones, J. Lowe, J. Murphy, D. Hassell, P. Boorman, R. McDonald, and S. Hill. 2002. Climate Change Scenarios for the United Kingdom: The UKCIP02 Scientific Report, UK Climate Impacts Programme, 2002.

Morgan, M. G., and M. Henrion. 1990. Uncertainty: A Guide to Dealing with Uncertainty in Quantitative Risk and Policy Analysis, Cambridge University Press, New York, NY. p.332. 
Ralston, W., and I. Wilson. 2006. The Scenario Planning Handbook, Thompson Southwestern, p.264.

Sayers, P. B., and I. C. Meadowcroft. 2005. RASP - A hierarchy of risk-based methods and their application. In Proceedings of the 40th Defra Flood and Coastal Management Conference, York, UK, 5-7 July 2005.

Thorne, C. R., E. P. Evans, and E. C. Penning-Rowsell. 2007. Future Flooding and Coastal Erosion Risks, Thomas Telford Publishing, London, p.514.

U.S. Army Corps of Engineers (USACE). 2008. HEC-FDA Flood Damage Reduction Analysis: User's Manual Version 1.2.4, Hydrologic Engineering Center, November, Davis, CA.

NOTE: The contents of this technical note are not to be used for advertising, publication, or promotional purposes. Citation of trade names does not constitute an official endorsement or approval of the use of such products. 